\title{
CNKSR1 Gene
}

National Cancer Institute

\section{Source}

National Cancer Institute. CNKSR1 Gene. NCI Thesaurus. Code C24303.

This gene plays a role in signal transduction via the receptor tyrosine kinase signaling pathway. 